\title{
Editorial
}

\section{Psychotropic drugs research in Nazi Germany: The triumph of de principle of malfeasance}

Biomedical research in pre-Nazi Germany could be considered among the most advanced of its time not only for its results but also for its ethical and legal regulations protecting research participants. Indeed, the medical community's considerable interest in the ethics of biomedical research was reflected in the Prussian government's promulgation, in 1900, of a series of ethical norms on experimentation in humans with new therapeutic tools, in the wake of the so-called 'Neisser case' scandal, in which prostitutes were used in research on a syphilis vaccine without being informed and without consent. Subsequently, in 1931, the Weimar Republic's Interior Ministry issued a series of Guidelines for New Therapies and Experimentation in Humans, incorporating the legal doctrine of informed consent and prohibiting experimentation with the dying and the economic and socially needy (1).

However, the coming to power of the National Socialist German Workers' Party (Nationalsozialistische Deutsche Arbeiterpartei, NSDAP) and the triumph of eugenicist and racial scientific theories (that gained more and more ground, especially in the Central European context, during the first third of the 20th century), abruptly interrupted this ethical development in research, which, formerly 'for the benefit of the patient', became based on the principle of 'for the benefit of the State'. Thus, when Adolf Hitler acceded to the Presidency, in accordance with the electoral promises that helped bring him to power, he began implementing racist policies in defence of a 'master race' $(2,3)$, like the Law for the Prevention of Hereditary Diseases of Descent (better known as the Sterilization Act), promulgated on 14 July 1933. In general, German medicine cannot be said to have dissociated itself from the eugenicist movements (the year 1909 saw the foundation of the German Society for Racial Hygiene). However, it would be unfair to attribute this connection exclusively to the German medicine because of eugenicist institutions and associations proliferating all over Europe, organising many conferences and scientific meetings. Indeed, in the name of the eugenics concept, sterilisation programmes were introduced in many Western countries, among them Denmark, Finland, Sweden and the United States (4).

Anthropological racism, medical somaticism, persecution of the abnormal or alien and so on, were some of the constituent elements of the political-social programme of the Nazi party. Thus, medical experimentation became just one more tool of political power and social control with increasingly evident military connotations.

In addition to the involvement of healthcare personnel in sterilisation and euthanasia programmes, the most disconcerting expression of the link between the medical community and the Nazi tragedy was the forced participation of human beings as research and laboratory material, not only in the infamous death camps but also in hospitals and universities. With specific regard to the use of psychotropic drugs, there is evidence of psychopharmacological research programmes, without the slightest ethical requirements or legal protection, in two specific groups of subjects: first, the mentally handicapped and mentally ill; and second, healthy subjects, usually from rejected ethnic or social groups (Jews, Gypsies, Slavs, etc.), recruited in concentration camps. As regards the former, some of those responsible for these projects justified them thus: If the patients have to die in any case, as a result of the expert assessment of one of my colleagues, why not use them while alive or after their execution for research? (5)

Although less well known than research in other medical fields, we shall describe, as examples, two relatively well-documented projects with 
neuropsychiatric patients (6). One of these was a wide-ranging programme on diverse forms of mental retardation and epilepsy directed by Carl Schneider (Professor of Psychiatry at Heidelberg) involving the assessment and exhaustive long-term study of live patients from the neuropsychological, physiological and therapeutic perspectives, and culminating in the anatomopathological study of their brains after subjecting them to the Euthanasia Programme (Operation T4). Schneider's correspondence reveals his great interest in obtaining the approval of the programme's assessors, and there is evidence that at least 194 brains were analysed in his department (7). In the other project, Professor Julius Hallervorden (sub-director of the Berlin-Buch Kaiser-Wilhelm Institut for Brain Research) coordinated, at one of the euthanasia centres within his jurisdiction (the Brandenburg asylum), the extraction of brains from recently executed patients. Knowing their diagnosis before execution, he was able to choose the most interesting brains for his research $(8,9)$. A report by the Combined Intelligence Operative Subcommittee (CIOS), catalogued as L-170, to the socalled Doctors' Trial at Nuremberg, specifies that 'Dr. Hallervorden obtained 500 brains from the centres for the killing centres for the insane. These patients were murdered in various institutions through inhalation of carbon monoxide'. In his testimony, Hallervorden stated 'there was wonderful material among those brains, beautiful mental defectives, malformations and early infantile diseases'. However, following the line typical of the Nazi medical class, he added '...Where they [the brains] came from and how they came to me was really none of my business' (10).

As regards the use of healthy prisoners, the deplorable human experiments by Nazi doctors were more common, and are better documented and better known today, in areas of medicine such as genetics, gynaecology, surgery or traumatology. It suffices to recall some of the experiments for which doctors were tried at Nuremberg, such as those involving freezing, inoculation with tuberculosis bacilli, amputation of limbs, or surgical sterilisation without anaesthetic. However, concentration camp prisoners likewise constituted the principal source of recruitment for pharmacological studies, in which other sectors of the Nazi regime's health system played a substantial role - principally the chemical-pharmaceutical industry, also linked to medical research in the death camps, where they could test drugs practically unfettered $(11,12)$. Especially prominent in this regard was the industrial giant IG Farben (Interessen-Gemeinschaft Farbenindustrie $A G$ ), closely associated with the Nazi hierarchy $(11,13)$. During World War II, IG Farben was involved in numerous cases related to criminal activities by the Nazi executive, including the use of slave labour in their installations close to the concentration camps, such as Monowitz, near Auschwitz. Moreover, it was here that they tried out different pharmacological substances, including sulphamate and arsenical derivatives and others whose composition is not precisely known (B-1012, B-1034, 3382 or Rutenol, 3582 or Acridine), generally for the treatment of infectious diseases, such as typhus, erysipelas, scarlet fever or paratyphoid diarrhoea, previously induced in subjects (11).

Among those responsible for these pharmacological projects were ex-IG Farben scientists, such as Medical Commander of the Schutzstaffel (SS) Helmuth Vetter, and doctors at the death camps, including the infamous Joseph Mengele $(12,14)$, although the ideologue of most medical experimentation in the camps, and the man with most responsibility for it, was Joachim Mrugowsky, Colonel-Director of the Waffen SS Hygiene Institute and Associate Professor at Berlin University: experiments with typhus vaccines, gaseous oedemas and lethal phenolic injections in Buchenwald; with different poisons in Sachsenhausen; with sulphanilamide in Ravensbrück; and with the generalised use of Zyklon-B gas in Auschwitz (14). In the field of psychopharmacology, there are reports of specific studies at different camps: at Buchenwald they studied the effects of the combined administration of methamphetamine and phenobarbital (15) and the anaesthetic properties of sodium hexobarbital with chloral hydrate in surgery on healthy subjects (16); at Dachau, mescaline was administered to assess the hidden schizophrenic behaviour of inmates or actually induce it (17); at Auschwitz-Birkenau, the psychiatrist Hans-Wilhelm König studied the effects of high-voltage electric shocks, not only in schizoid patients, but also in healthy prisoners, making an anatomopathological study of the brains after death (14). The level of amorality and ethical degradation of the Nazi medical community is reflected in a letter found among the files at Auschwitz, exemplifying the correspondence between the camp Commandant and certain departments of IG Farben. The latter applied to purchase prisoners for research on a hypnotic drug: 'We need some 150 women in the best possible state of health... We confirm your response, but consider the price of 200 marks per woman too high. We propose paying no more than 170 marks per woman... The experiments were carried out. All of these persons died. We will contact you shortly about a new shipment...' (12).

In any case, it remains to ponder the motives and circumstances that led to the abuses described here, 
although this is a priori a rather difficult question to tackle. It is certainly true that, in the atmosphere of generalised enthusiasm in the early years of the Third Reich, the doctors involved in the application of eugenicist laws, and those who passively accepted them, argued that the norms were conceived for the benefit of the nation (Volksgesundheit) and not for the patient, if they were to leave a legacy of health for the coming generations $(3,18)$, implying the invocation of such deceptive and coercive concepts as cause majeure or 'sacred mission' $(14,19)$. However, there must also have been many other types of motivation in the members of the medical and scientific community for participating directly in the tremendous abuses committed during the Nazi regime (20): some believed that everything was justified in the name of science, including the inhuman experiments carried out during the Second World War in the concentration camps (21); others simply saw themselves as patriots, and justified their behaviour as acts of war; many became feverishly imbued with the perverse Nazi philosophy, while still others, more driven by ambition, became involved in such activities with a view to promoting their professional and academic careers. Finally, it is also important to stress that uncoupling oneself completely from the sinister Nazi machinery could become quite difficult for the health community (22), especially in an atmosphere in which fear was an essential tool of social pressure.

Many of these activities came to light at the famous trials against Nazi leaders and other war criminals by an International Military Tribunal in Nuremberg between 1945 and 1949. At the Doctors' Trial (United States of America vs. Karl Brandt, et al.), some of those responsible for these experimental atrocities, such as Mrugowsky and Waldemar Hoven (23), were sentenced to death, although others evaded justice, including Mengele himself, who escaped to South America, where he died a natural death (24). Other scientists, as Hallervorden or Ernst Rüdin, one of the key players in the eugenicist policies of the Nazi regime, returned to his academic posts after the War. It is more, in the post-war, Hallervorden published numerous scientific works based on materials obtained during the dark years of the T4 Aktion, as some articles on the effect of the carbon monoxide in the foetuses brain development (25).

The same year as that trial ended there began another (in August 1947), also at Nuremberg (United States of America vs. Carl Krauch, et al.), popularly known as the IG Farben Trial, involving 24 executives and scientists from the chemical-pharmaceutical corporation, and also for 'crimes against humanity', among other offences (experiments with prisoners, use of slave labour, abuse, torture and murder of prisoners, etc.). The sentences in this case were considerably lighter (8 years' prison the most severe), partly because of the dearth of incriminating documentary evidence, unsurprising in view of the operation, after September 1944 and as the Allies advanced, to destroy all the corporation's compromising files (11).

The response to the atrocities committed by Nazi doctors and scientists in human research, revealed at the Nuremberg trials, was the emergence of the first international code of ethics for research with human beings, the Nuremberg Code, guided by the Hippocratic precept of primum non nocere (6). This Code, whose aim was to prevent any repetition of such tragic direct attacks on people's rights and wellbeing, was published on 19 August 1947, setting down the norms for experimentation with human beings and with special insistence on the need for participants' voluntary consent (26). But the most tragic aspect of all this is that these types of activities and practices continued to take place subsequently, mainly in countries governed by totalitarian regimes, such as the former Soviet Union (27) and the People's Republic of China, essentially within the framework of political and religious repression. Nevertheless, the information available in relation to these countries is extremely scarce because the activities in question have never reached public knowledge as they did in the West so that those responsible have never been brought to justice.

In any case, real contributions to medical scientific progress of the criminal research programmes run by the Nazis were practically nonexistent. In the words of Leo T. Alexander, one of the American medical consultants for the prosecution at Nuremberg, and inspirer of the Nuremberg Code: 'the result was a significant advance in the science of killing, or ktenology' (28).

\section{Francisco López-Muñoz, Cecilio Álamo Department of Pharmacology, Faculty of Medicine, University of Alcalá, Madrid, Spain}

\section{References}

1. Vollman J, Winau R. Informed consent in human experimentation before the Nuremberg code. $\mathrm{Br}$ Med $\mathbf{J}$ 1996;313:1445-1447. 
2. Wertham F. A sign for Cain. New York: The Macmillan Co, 1966.

3. Bachrach S. In the name of public health - Nazi racial hygiene. New Engl J Med 2004;351:417-419.

4. Proctor RN. Racial hygiene: Medicine under the Nazis. Cambridge: Harvard University Press, 1988.

5. Seidelman WE. Nuremberg lamentation: for the forgotten victims of medical science. Br Med J 1996;313:1463-1467.

6. López-Muñoz F, Alamo C, Dudley M et al. Psychiatry and political-institutional abuse from the historical perspective: the ethical lessons of the Nuremberg Trial on their 60th anniversary. Prog Neuropsychopharmacol Biol Psychiatry 2007;31:791-806.

7. Weigmann K. In the name of science. The role of biologists in Nazi atrocities: lessons for today's scientists. EMBO Rep 2001;2:871-875.

8. Friedlander $H$. The origins of Nazi genocide: from euthanasia to the Final Solution. Chapel Hill: University of North Carolina Press, 1995.

9. Goldhagen D. Hitler's willing executioners: ordinary Germans and the Holocaust. New York: Knopf, 1996.

10. Harvard Law School Library. Nuremberg Trials Project. A Digital Document Collection. Item No. 170 [cited 5 May 2008] URL: http://www.law.harvard.edu/library/collections/ digital/war_crime_trials_nuremberg.php

11. Borkin J. The Crime and Punishment of I.G. Farben. New York: Free Press, 1978.

12. Coordination gegen Bayer-Gefahren (red.). IG-Farben; Von Anilin bis Zwangsarbeit. Stuttgart: Schmetterling Verlag, 1995.

13. Schneckenberger A. Die Geschichte des IG Farben Konzerns. Köln: Paul Regenstein, 1988.

14. Lifton R. The Nazi doctors: medical killing and the psychology of genocide. New York: Basic Books, 1986.
15. Sofsky W. The order of terror: the concentration camp. Princeton: Princeton University Press, 1997.

16. Hackett DA. The Buchenwald Report. San Francisco: Westview Press, 1995.

17. KLEE E. Auschwitz, die NS-Medizin und ihre Opfer. Frankfurt: Fischer (S), 1997.

18. Biéder J. German social psychiatry in 1934. Ann Med Psychol (Paris) 1996;154:147-151.

19. Dudley M, Gale F. Psychiatrist as a moral community? Psychiatry under the Nazis and its contemporary relevance. Austral NZ J Psychiatry 2002;36:585-594.

20. Michalczyк J. Médical ethics in the Third Reich. Kansas City: Sheed and Ward, 1994.

21. Hunter E. The snake on the Caduceus: dimensions of medical and psychiatric responsibility in the Third Reich. Austral NZ J Psychiatry 1993;27:149-156.

22. Benedict S, Chelouche T. Meseritz-Obrawalde: a 'wild euthanasia' hospital of Nazi Germany. Hist Psychiatry 2008;19:68-76.

23. Mitscherlich A, Mielke F. Doctors of infamy: the story of the Nazi medical crimes. New York: Schuman, 1949.

24. Curran WJ. The forensic investigation of the death of Joseph Mengele. New Engl J Med 1986;315:1071-1073.

25. Peiffer J. Assessing neuropathological research carried out on victims of the 'Euthanasia' Programme. Med Hist $\mathbf{J}$ 1999;34:339-356.

26. SHuster E. Fifty years later: the significance of the Nuremberg Code. New Engl J Med 1997;337:1436-1440.

27. BLoch S. Political misuse of psychiatry in the Soviet Union. In: Bloch S, Chodoff P, eds. Psychiatric Ethics, 2nd edn. Oxford: Oxford University Press, 1991: 493-517.

28. Alexander L. Medical science under dictatorship. New Engl J Med 1949;241:39-47. 